\title{
СТВОРЕННЯ БАНКІВСЬКИХ КЛАСТЕРІВ ДЛЯ ПІДВИЩЕННЯ ІННОВАЦЙНОСТІ БАНКІВСЬКОЇ СИСТЕМИ УКРАЇНИ
}

\author{
DOI: 10.32620/cher.2019.3.07
}

\begin{abstract}
Постановка проблеми. Більшість розвинутих країн світу сьогодні пов'язують довгострокове стійке економічне зростання $з$ переходом на інноваційний шлях розвитку, тому проблема створення та забезпечення ефективного функціонування інноваційних кластерних структур, зокрема банківських, наразі є вкрай актуальною. Метою статmі $\epsilon$ узагальнення теоретико-методологічних положень щодо створення банківських кластерних структур для підвищення інноваційності банківської системи України. Предмет дослідження - формування та функціонування інноваційних банківських кластерів в Україні. Методи, використані в дослідженні: логічно-змістовний метод, метод порівняння, методи індукції та дедукції, кластерний аналіз тощо. Гіпотеза дослідження. Наявність необхідності формування інноваційних банківських кластерів для підвищення інноваційності та конкурентоспроможності банківської системи України. Виклад основного матеріалу. Проаналізовано визначення понять «інноваційний кластер» і «банківські інновації», визначено, що банківські інновації в Україні зараз спрямовані переважно на створення нових або модернізацію існуючих банківських продуктів та послуг та на розвиток автоматизованих банківських систем. Визначено переваги створення інноваційних банківських кластерів та розроблено алгоритм здійснення кластерного аналізу банків і алгоритм створення інноваційних банківських кластерів. Оригінальність та практичне значення дослідження полягають в розробленні алгоритму здійснення кластерного аналізу банків і алгоритму створення інноваційних банківських кластерів, що дозволяє визначити послідовність дій, необхідних для формування кластерних структур. Висновки дослідження. Охарактеризовано перспективи створення інноваційних банківських кластерів та розроблено алгоритм здійснення кластерного аналізу банків і алгоритм створення інноваційних банківських кластерів, що дозволить сформувати інноваційний банківський кластер, який забезпечить тісну взаємодію між членами кластеру й генерацію нових ідей, дасть змогу підвищити іноваційність виробництва та процесу надання банківських послуг.
\end{abstract}

Ключові слова:

алгоритм, банківські інновації, інноваційні банківські кластери, кластерний аналіз, перспективи.

\section{BANKING CLUSTERS CREATION FOR UKRAINE BANKING SYSTEM INNOVATIVITY INCREASING}

Formulation of the problem. Today most developed countries associate long-term sustainable economic growth with the transition to innovative path of development, so the problem of creating and ensur-

${ }^{1}$ Татар Марина Сергіївна, канд. екон. наук, доцент кафедры «Фінанси», Національний аерокосмічний університет ім. М.С. Жуковського «Харківський авіаційний інститут», м. Харків, Україна.

Tatar Maryna, Ph.D. in Economics, Associate professor of the Finance Department, National Aerospase University «Kharkiv Aviation Institute», Kharkiv, Ukraine.

ORCID ID: 0000-0002-1111-7103

e-mail: marina.sergeevna.tatar@gmail.com

${ }^{2}$ Нужнова Юлія Анатоліївна, канд. наук держ. упр., доцент кафедри «Фінанси», Національний аерокосмічний університет ім. М.С. Жуковського «Харківський авіаційний інститут», м. Харків, Україна.

Nuzhnova Yulia, Ph.D. in Public Administration, Associate Professor of the Finance Department, National Aerospase University «Kharkiv Aviation Institute», Kharkiv, Ukraine.

ORCID ID: 0000-0003-2939-6435

e-mail: nughnoww@rambler.ru

${ }^{3}$ Косяк Олексій Олегович, магістрант спеціальності «Фінанси, банківська справа та страхування», Національний аерокосмічний університет ім. М. Є. Жуковського «Харківський авіаційний інститут», м. Харків, Україна.

Kosyak Oleksiy, Master's degree of Finance, Banking and Insurance Specialty»of National Aerospase University «Kharkiv Aviation Institute», Kharkiv, Ukraine.

ORCID ID: 0000-0002-6558-1139

e-mail: alekseykosyak94@gmail.com 
ing the efficient functioning of innovative cluster structures, in particular banking, is extremely urgent. The aim of the research is systematization of theoretical and methodological provisions on the creation of banking cluster structures to enhance the innovativeness of Ukraine banking system. The subject of the research is formation and functioning of innovative banking clusters in Ukraine. The methods of the research: meaningful method, comparison method, induction and deduction methods, cluster analysis, etc. The hypothesis of the research. There is a need to create innovative banking clusters to increase the innovativeness of the Ukraine banking system. The statement of basic materials. The definitions of the term "innovation cluster" and "banking innovations" are analyzed. It is determined that banking innovations in Ukraine are aimed mainly at creating new or modernizing existing banking products and services and developing automated banking systems. The advantages of creation of innovative banking clusters are characterized and algorithm of banks cluster analysis realization and algorithm of innovative banking clusters creation are developed. The originality and practical significance of the research are algorithm of banks cluster analysis realization and algorithm of innovative banking clusters creation, which makes possible to determine the sequence of actions required for cluster structures formation. Conclusions and perspectives of further research. Prospects of creation of innovative banking clusters are characterized and algorithm of banks cluster analysis realization and algorithm of innovative banking clusters creation are developed. These algorithms will ensure close interaction between the cluster members and the generation of new ideas, will increase the innovativeness of the production and providing of banking services.

\section{Key words:}

algorithm, banking innovations, innovative banking clusters, cluster analysis, prospects.

\section{СОЗДАНИЕ БАНКОВСКИХ КЛАСТЕРОВ ДЛЯ ПОВЫШЕНИЯ ИННОВАЦИОННОСТИ БАНКОВСКОЙ СИСТЕМЫ УКРАИНЫ}

Постановка проблемы. Большинство развитых стран мира сегодня связывают долгосрочный устойчивый экономический рост с переходом на инновационный путь развития, поэтому проблема создания и обеспечения эффективного функционирования инновационных кластерных структур, в частности банковских, в данный момент является крайне актуальной. Целью статьи является обобщение теоретико-методологических положений по созданию банковских кластерных структур для повышения инновационности банковской системы Украины. Предмет исследования - формирование и функционирование инновационных банковских кластеров в Украине. Memodbl, ucnoльзуeмые в исследовании: логически-содержательный метод, метод сравнения, методы индукции и дедукции, кластерный анализ и др. Гипотеза исследования. Наличие необходимости формирования инновационных банковских кластеров для повышения инновационности и конкурентоспособности банковской системы Украины. Изложение основного материала. Проанализированы определения понятий «инновационный кластер» и «банковские инновации», определено, что банковские инновации в Украине сейчас направлены преимущественно на создание новых или модернизацию существующих банковских продуктов и услуг, на развитие автоматизированных банковских систем. Определены преимущества создания инновационных банковских кластеров и разработан алгоритм осуществления кластерного анализа банков и алгоритм создания инновационных банковских кластеров. Оригинальность и практическое значение исследования заключаются в разработке алгоритма осуществления кластерного анализа банков и алгоритма создания инновационных банковских кластеров, что позволяет определить последовательность действий, необходимых для формирования кластерных структур. Выводы исследования. Охарактеризованы перспективы создания инновационных банковских кластеров и разработан алгоритм осуществления кластерного анализа банков и алгоритм создания инновационных банковских кластеров, что позволит сформировать инновационный банковский кластер, который обеспечит тесное взаимодействие между членами кластера и генерацию новых идей, позволит повысить инновационность производства и процесса предоставления банковских услуг.

\section{Ключевые слова:}

алгоритм, банковские инновации, инновационные банковские кластеры, кластерный анализ, перспективы.

Постановка проблеми. Наразі в Україні відбувається активна модернізація банківської системи шляхом упровадження інновацій, які спрямовані головним чином на розвиток дистанційного банківського обслугову- вання, удосконалення інформаційнокомунікаційних та комп'ютерних технологій для створення єдиного інформаційноекономічного простору банківської системи України, а також на управління ризиками i 
формування системи інформаційної безпеки в банківському секторі. Проте аналіз тенденцій розвитку банківської системи за 2014-2018 рр. показує, що кількість банків в Україні у 2018 p. суттєво зменшилася порівняно 32014 p. Зокрема, у 2014 р. в Україні було зареєстровано 162 банки, у 2018 р. залишилося лише 77 банків, що свідчить про непластоспроможність та збитковість діяльності банків, незадовільну якість управління, яка не завжди відповідає рівням розвитку банківських систем розвинутих країн світу. Для забезпечення виживання на ринку, стабільної діяльності банків й підвищення їх конкурентоспроможності необхідне посилення інноваційних процесів й економічної ефективності інноваційної діяльності банків, спрямованих на зростання прибутковості при допустимому рівні ризику, а також формування інноваційних банківських кластерів як фактора забезпечення інноваційності економіки України на шляху до євроінтеграції.

Аналіз останніх досліджень i публікацій. Аналізом розвитку кластерів займалися багато вітчизняних та закордонних науковців, зокрема I. Брикова, М. Войнаренко, А. Єрмишина, О. Каніщенко, С. Соколенко, С. Монастирний, Е. Бергман, М. Портер, Е. Фезер, Г. Хасаєв тощо.

В свою чергу дослідженню теоретикометодологічних та практичних аспектів фор- мування інноваційних кластерів в контексті активізації інноваційної діяльності присвячені праці таких зарубіжних вчених як А. Брувер, Е. Леммер, А. Маршал, а також українських вчених М. Войнаренко, В. Геєць, Д. Лук'яненко, В. Новицький, С. Соколенко, М. Тимчук, А. Філіпенко тощо. Однак, бажано більш детально охарактеризувати проблеми та перспективи створення інноваційних банківських кластерів та розробити алгоритм здійснення кластерного аналізу банків і алгоритм створення інноваційних банківських кластерів.

Метою статті є узагальнення теоретико-методологічних положень щодо створення банківських кластерних структур для підвищення інноваційності банківської системи України.

Виклад основного матеріалу дослідження. Метою створення інноваційних банківських кластерів $є$ підвищення конкурентоспроможності банків-членів кластеру внаслідок здійснення взаємного співробітництва, проведення наукових досліджень щодо створеня інноваційних продуктів, впровадження інновацій, освіти, навчання і заходів політики підтримки. Концепція інноваційних кластерів має різні значення в різних країнах і у різних дослідників (табл. 1).

Визначення поняття «інноваційний кластер»

Т а б ли ц я 1

\begin{tabular}{|c|c|c|}
\hline \multicolumn{3}{|r|}{ Визначення поняття «1нновациинии кластер» } \\
\hline $\begin{array}{c}\text { № } \\
\Pi / \Pi\end{array}$ & Автор & Визначення \\
\hline 1 & 2 & 3 \\
\hline 1 & Бірюков А.I. & $\begin{array}{l}\text { Інноваційний кластер - цілеспрямовано сформована група суб’єктів, } \\
\text { що функціонують на базі центрів генерації наукових знань і бізнес- } \\
\text { ідей, підготовки висококваліфікованих фахівців }\end{array}$ \\
\hline 2 & Єжакова Н.В. & $\begin{array}{l}\text { Інноваційний кластер - інтегрований осередок генерації наукових } \\
\text { знань, ідей, центрів підготовки висококваліфікованих кадрів, які } \\
\text { випускають інноваційну і наукомістку продукцію, що має дов- } \\
\text { гострокові конкурентні переваги }\end{array}$ \\
\hline 3 & $\begin{array}{l}\text { Мігранян А.А., } \\
\text { Разуєв І.Г., } \\
\text { Дивак В.В. }\end{array}$ & $\begin{array}{l}\text { Інноваційний кластер - об’єднання різних організацій (промислових } \\
\text { компаній, вищих навчальних закладів, технопарків і бізнес- } \\
\text { інкубаторів, науково-дослідних центрів і лабораторій, банківських і } \\
\text { позабанківських кредитних організацій, інвестиційно-інноваційних } \\
\text { компаній, венчурних фондів, органів державного управління, гро- } \\
\text { мадських організацій і т.д.), яке дозволяє використовувати переваги } \\
\text { внутрішньофірмової ієрархії та ринкового механізму, що дає мож- } \\
\text { ливість більш швидко та ефективно розподіляти нові знання, наукові } \\
\text { відкриття та винаходи }\end{array}$ \\
\hline 4 & Олійник А.Д. & $\begin{array}{l}\text { Інноваційний кластер - упорядкована, добровільно об’єднана сукуп- } \\
\text { ність економічних суб’єктів, які здатні проектувати та виготовляти } \\
\text { спеціалізовану конкурентоспроможну на світовому ринку продукцію }\end{array}$ \\
\hline
\end{tabular}


Продовження табл. 1

\begin{tabular}{|c|c|c|}
\hline 1 & 2 & 3 \\
\hline 5 & $\begin{array}{c}\text { Монастирний Є.О., } \\
\text { Шовкалюк В.С. }\end{array}$ & $\begin{array}{l}\text { Інноваційний кластер - цілісна система підприємств та організацій } 3 \\
\text { виробництва готового інноваційного продукту, що включає весь ін- } \\
\text { новаційний ланцюг від розвитку фундаментальної наукової ідеї до } \\
\text { виробництва та дистрибуції готової продукції }\end{array}$ \\
\hline 6 & Кузьміна Ю.Д. & $\begin{array}{l}\text { Інноваційний кластер - механізм стратегічної взаємодії підприємств, } \\
\text { дослідних організацій, університетів, венчурних фондів та інших } \\
\text { посередницьких структур, що забезпечує синергетичний ефект } \\
\text { взаємної підтримки виробництва нової інноваційної продукції та по- } \\
\text { слуг }\end{array}$ \\
\hline 7 & Саяпіна К.В. & $\begin{array}{l}\text { Інноваційний кластер - група інноваційних стартапів, малих, се- } \\
\text { редніх і великих суб’єктів господарювання, а також науково- } \\
\text { дослідних центрів, що діють у певній галузі, де стимулювання до } \\
\text { ведення інноваційної діяльності відбувається шляхом постійної ак- } \\
\text { тивної взаємодії, спільного використання наявних ресурсів, обміну } \\
\text { знаннями та досвідом, а також завдяки передачі технологічних особ- } \\
\text { ливостей, системності та розповсюдження інформації серед усіх } \\
\text { учасників кластера з урахуванням існуючого інноваційного потен- } \\
\text { ціалу та інноваційного потенціалу розвитку }\end{array}$ \\
\hline
\end{tabular}

Національний банк України ще у 2015 р. перейшов на кластерний підхід щодо нагляду за банками, які поділено на кластери за схожими бізнес-моделями, профілями ризиків та характером здійснюваних операцій чи іншими притаманними ознаками [8].

Наразі пропонується створення інноваційних банківських кластерів 3 метою об'єднання банків, найбільш спроможних до банківських інновацій.

Авторами пропонується кластеризація банків на такі групи:

- інноваційно-активні банки - банки, які вже протягом тривалого періоду часу активно впроваджують інноваційні банківські продукти і послуги;

- банки, потенційно здатні до інновацій, однак, які внаслідок деяких причин не здійснюють активну інноваційну діяльність;
- банки, не спроможні до інновацій банки, які характеризуються неплатоспроможністю та збитковістю, незадовільною структурою балансу тощо.

Зазначимо, що сьогодні в Україні найбільш інноваційно-активними банками $є$ «ПриватБанк», «Райффайзен банк Аваль», «Альфа-Банк», «ОТП Банк», які вже більше десятиріччя виділяються поміж інших банків наданням інноваційних продуктів, зокрема SMS-банкінгу та Інтернет-банкінгу [8].

Для всебічного розуміння і правильного поділу банків на інноваційно активні, потенціально здатні до інновацій та неспроможні до інновацій слід проаналізувати суть банківських інновацій (табл. 2).

Визначення поняття «банківські інновації»

\begin{tabular}{|c|c|l|}
\hline № п/п & Автор & \multicolumn{1}{c|}{ Визначення } \\
\hline 1 & 2 & \multicolumn{1}{c|}{3} \\
\hline \multirow{1}{*}{1} & Сгричева С.Б. & $\begin{array}{l}\text { Банківські інновації у вузькому значенні - це впровадження нових або } \\
\text { суттєво вдосконалених банківських продуктів і послуг, які відповіда- } \\
\text { ють існуючим або потенційним фінансовим потребам клієнтів, влас- } \\
\text { ним інтересам банку та вимогам банківського законодавства, надають } \\
\text { зацікавленим сторонам додаткові вигоди та є результатами банківсь- } \\
\text { кого інжинірингу. У широкому розумінні - це процес створення до- } \\
\text { даткової цінності для клієнтів, працівників та власників банку шляхом } \\
\text { внесення якісних змін в усі сфери його діяльності - продукти, послу- } \\
\text { ги, процеси, бізнес-моделі та стратегії, що стали результатом практич- } \\
\text { ної реалізації нових ідей, знань та стороннього досвіду }\end{array}$ \\
\hline
\end{tabular}


Продовження табл. 2

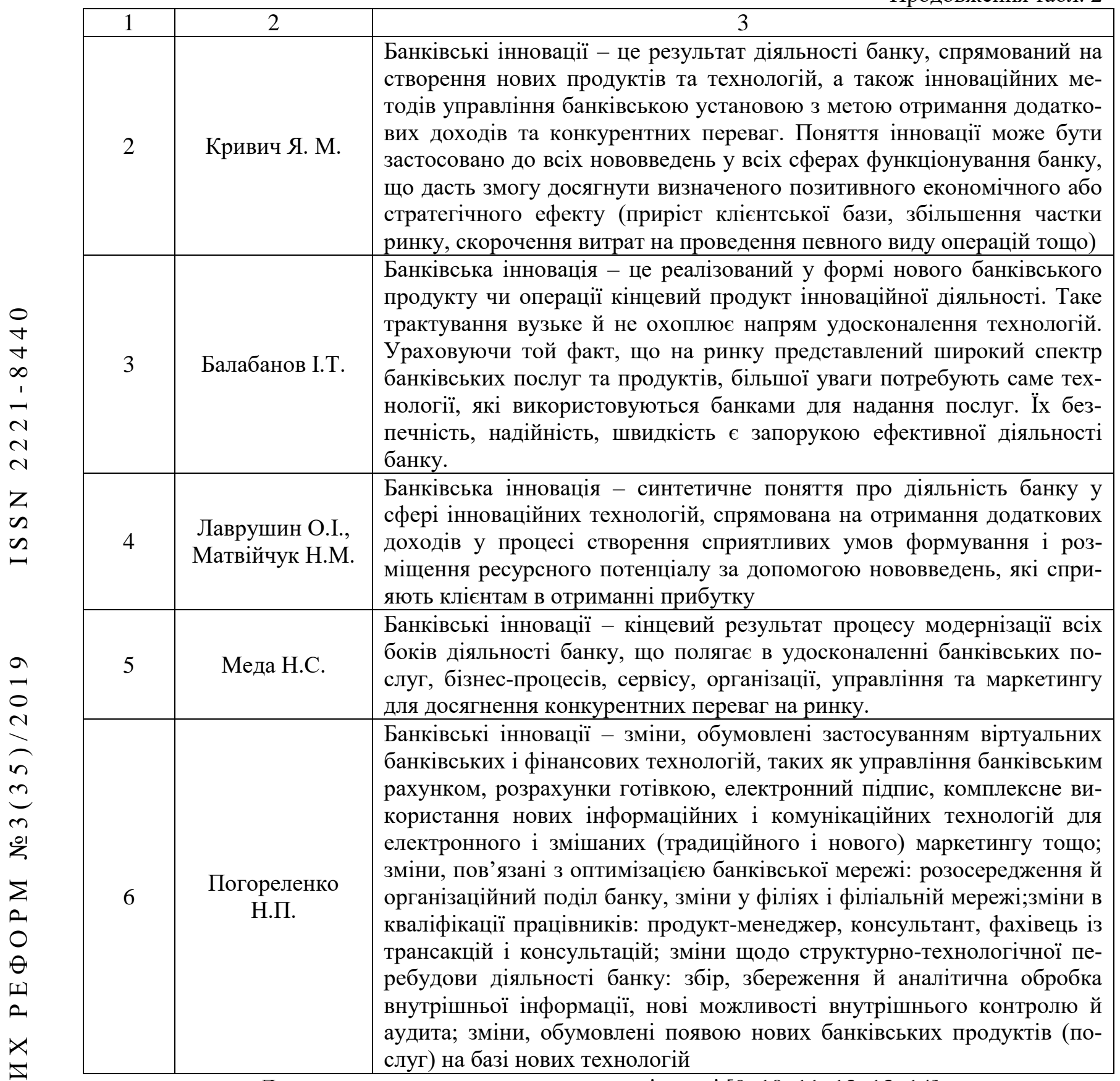

Джерело: узагальнено авторами на підставі $[9,10,11,12,13,14]$

О. В. Золотарьова вважає, що причиною появи банківських інновацій, з одного боку, $є$ підтримка банком стійкого зв'язку $з$ клієнтами, яка заснована на партнерських відносинах. Це означає, що банки турбуються не тільки про збереження, а й про примноження капіталу своїх клієнтів. Досягають вони цього тим, що пропонують інноваційні продукти, які, своєю чергою, сприяють розширенню напрямів їх діяльності, зниженню витрат, розвитку ділової активності і підвищенню прибутковост [15]. 3 іншого боку, передумовою появи банківських інновацій $є$ конкуренція між банківськими та іншими фінансовими інститутами в умовах постійного розвитку фінансового ринку.

У міжнародній практиці зазвичай виділяють наступні види банківських інновацій:

- банківський продукт на нових сегментах ринку;

- інновації як освоєння напрямів діяльності у нових сферах фінансового ринку;

- нові методи управління готівкою та використання нових інформаційних банківських технологій;

- модифіковані послуги фінансового посередництва, спрямовані на зниження опе- 
раційних витрат та більш ефективне управління активами та зобов'язаннями;

- нові продукти в традиційних сегментах капіталів [16].

Отже, аналіз визначення поняття банківських інновацій дозволяє виділити такі основні їх ознаки:

- новизна споживчих властивостей продукту, поліпшення якості банківських продуктів і послуг, що дозволяе збільшити частку ринку і доходи банку;

- підвищення продуктивності праці завдяки поліпшенню операційної, фінансової, маркетингової, технологічної, кадрової, організаційної діяльності банків;

- підвищення інтенсивності діяльності внаслідок зниження витратності банківської діяльності, зокрема ресурсів (фінансових, людських, матеріальних) на одиницю активів;

- зниження ризиків і підвищення ліквідності банківських інноваційних продуктів;

- практичне впровадження новацій, нововведення та вихід інновацій на конкурентний ринок;

- підвищення ефективності діяльності, конкурентоспроможності та сприяння виходові на новий рівень розвитку;

- посилення глобалізаційних факторів, зростання міжнародного характеру інновацій, зокрема цьому сприяють інновації, пов'язані 3 технологіями дистанційного обслуговування тощо.

Банківські інновації в Україні зараз спрямовані переважно на створення нових або модернізацію існуючих банківських продуктів та послуг та на розвиток автоматизованих банківських систем.

Найбільш розповсюдженими $є$ такі види вітчизняних інноваційних банківських продуктів:

- мобільний банкінг, завдяки якому можна здійснити більшість операцій із власними рахунками, який відкриває великий спектр послуг, зокрема, залишок по рахунку, платежі, перекази коштів, кредити однієї фізичної особи іншій тощо. За допомогою NFC-чіпів, які вбудовані у телефон, буде відбуватися ідентифікація клієнта, тому зникне потреба в паспорті, тому що ідентифікація клієнта банком стане можливою лише за допомогою телефона. Сьогодні ця тенденція з'явилася на ринках США і Свропи, де ідентифікація вже відбувається навіть за адресою електронної пошти клієнта;
- Інтернет-банкінг - ключова новація майбутнього десятиліття, яка сьогодні пропонується клієнтам більшістю банків. Україна входить у топ-10 країн Свропи за кількістю користувачів, але через низьке проникнення в регіони все ще має значний потенціал зростання Інтернет-аудиторії у майбутньому. Для банків це відкриває великі можливості, тому експерти роблять основну ставку саме на розвиток віддаленого банкінгу;

- «3она 24» - за допомогою цього продукту клієнт може самостійно керувати своїми рахунками, одержувати консультацію фахівця call-центру, залишати заявку на одержання послуги, записатися на обслуговування в будь-яке відділення банку. Практично кожна «зона 24» оснащена банкоматом, модулем поповнення готівкою CashIn, телефоном доступу до інформаційної служби. Цей напрямок банківської діяльності продовжує удосконалюватися;

- електронний залишок - упровадження даної послуги в касах банку дозволяє скоротити витрати на обіг монет, оскільки залишок менше однієї гривні зараховується на рахунок мобільного телефону клієнта або у вигляді електронного ваучера;

- POS-термінали в торговельних мережах - на відміну від західних країн вони не призвели до глобальної революції в українському безготівковому просторі. Однак сьогоднішні $15 \%$ безготівкових операцій 3 платіжними картками все-таки змушують банкірів вірити в посилення цього тренду в найближчі п'ять років. У майбутньому POSтермінали будуть установлювати самі торговці, оскільки в оплату будуть прийматися не пластикові картки, а інформація з NFCчіпів, вбудованих у телефон. Тим часом термінали самообслуговування, що з'явилися кілька років тому, набирають популярності як у банківських відділеннях, так і за їхніми межами [18].

- освоєння нового сегмента - банкінгу через соціальні мережі.

Інновації у розвитку автоматизованих банківських систем сприяли поділу зазначених систем на три рівні:

1. OLTP (англ. online transaction processing - оперативне виконання транзакцій) - сукупність модулів забезпечення поточної операційної роботи банку і є основою автоматизації банківської діяльності. 
2. OLAP (англ. online analytical processing - оперативний аналіз) - система аналітичної обробки даних, яка має на меті виконання операцій 3 агрегування та консолідації інформації, розрахунку фінансових показників, виявлення асоціативних зв'язків, здійснення фінансового аналізу, формування звітів для менеджерів банку тощо. Цей рівень для ефективного функціонування потребує створення Data Warehouse - централізованого сховища даних, що дає змогу суттєво здешевити та прискорити пошук інформації для прийняття управлінських рішень і складання аналітичних звітів, поліпшує якість управління ризиками та підвищує прозорість бізнесу. Також, незважаючи на значну вартість реалізації проекту, відповідні витрати досить швидко окуповуються.

3. DSS (англ. decision support system система підтримки прийняття рішень) - становить складні алгоритми аналізу та моделювання процесів для підготовки варіантів управлінських рішень.

Найбільш цікавими перспективними банківськими інноваціями, які запроваджені за кордоном й могли б бути започатковані в Україні, можуть бути:

1. Депозитний проект SmartyPig від WestBank (Великобританія), який побудова- ний за принципом соціальної мережі, де треба зареєструватися, виставити цілі, на які призначено вклад, запросити друзів. Такий вклад носить дуже конструктивний характер - людині прищеплюється звичка постійно усвідомлювати свої потреби та визначати способи їх досягнення.

2. Проект Keеp the change від Bank of America, згідно з яким банк у процесі покупки округлює суму, а різницю залишає клієнту на окремому ощадному рахунку.

3. IBC Bank (Канада), що пропонуе своїм клієнтам нову кредитну карту - «Кобренд» у співробітництві з відомою мережею ресторанів Tim Hortons. При здійсненні покупки або оплати рахунку в ресторані клієнт обирає потрібну йому кнопку і проводить платіж.

Ключовими напрямками вдосконалення інноваційної діяльності для комерційних банків України $є$ необхідність побудови алгоритму здійснення кластерного аналізу банків (рис. 1), а також алгоритму створення інноваційних банківських кластерів, який, в свою чергу, передбачає організаційну послідовність дій, необхідних для створення кластеру в реальній економіці (рис. 2).

Етап 1. Визначення цілей і задач здійснення кластерного аналізу

Етап 2.Вибір методу кластеризації та метрики відстаней

Етап 3. Визначення вибірки банків для кластеризації

Етап 4. Вибір показників, за якими будуть оцінюватися банки у вибірці

Етап 5. Визначення необхідної кількості кластерів

Етап 6. Оцінювання, аналіз та візуалізація отриманих результатів

Етап 7. Розробка рекомендацій та пропозицій щодо посилення інноваційності банків для кожного з виділених кластерів

Рис. 1. Алгоритм здійснення кластерного аналізу банків Джерело: розроблено авторами на підставі [17] 
4. Сервіс Р2Р-перекази через мобільний телефон, який представлений на ринку банківських послуг як Obopay, Hal-Cash от Bankinter, POPmoney от PNCBank. Суть його полягає в тому, що для переказу грошей не потрібно знати прізвище, банк та номер рахунку. Все, що потрібно, - це зареєструватися в проекті Р2Р-переказів і відправити гроші, натиснувши кнопки на телефоні. Якщо телефон уже $є$ в системі і він прив'язаний до рахунку в банку, то гроші прийдуть на нього, а якщо номера в системі немає, то рахунок буде відкрито автоматично [15].

Таким чином, створення банківських кластерів дасть змогу:

- посилювати процеси спеціалізації i розподіл праці між членами кластеру;

- більше приваблювати клієнтуру, створюючи тісну взаємодію між членами кластеру;
- знижувати вартість одиниці банківської послуги, яка виробляється на основі спільної діяльності;

- посилювати потоки ідей і інформації між членами кластеру;

- підвищувати іноваційність виробництва та процесу надання банківських послуг;

- ефективніше використовувати наявні банківські ресурси;

- створювати умови стабільності та розвитку організаційно-економічних зв'язків між суб'єктами кластера;

- створювати здоровий соціальний капітал, забезпечувати баланс ринкової ефективності і соціальної гармонії.

Етап 1. Визначення мети та спонукальних мотивів формування інноваційних банківських кластерів

Етап 2. Збір і оброблення інформації щодо можливостей, загроз, сильних і слабких сторін створення інноваційних банківських кластерів

Етап 3. Розробка організаційного проекту банківських кластерів

Етап 4. Формування організаційно-правових положень створення інноваційних банківських кластерів

Етап 5. Формування системи фінансово-кредитних відносин між членами кластера

Етап 6. Координація діяльності інноваційних банківських кластерів

Етап 7. Визначення ефективності функціонування інноваційних банківських кластерів

Етап 8. Порівняння ефективності функціонування інноваційних банківських кластерів з плановими (бажаними) результатами

Рис. 1. Алгоритм створення інноваційних банківських кластерів Джерело: розроблено авторами на підставі $[15,18,21,22]$

Висновки та перспективи подальших досліджень. Здійснено аналіз визначень понять «інноваційний кластер» і «банківські інновації», визначено, що банківські інновації в Україні зараз спрямовані переважно на створення нових або модернізацію існую- чих банківських продуктів та послуг та на розвиток автоматизованих банківських систем. Охарактеризовано перспективи створення інноваційних банківських кластерів та розроблено алгоритм здійснення кластерного аналізу банків і алгоритм створення інно- 
ваційних банківських кластерів. Подальше дослідження буде спрямоване на формування системи показників, які характеризують інноваційну діяльність окремих банків України, здійснення кластерного аналізу банків й визначення групи інноваційноактивних банків, групи банків, потенційно здатних до інновацій, однак, які внаслідок деяких причин не здійснюють активну інноваційну діяльність та банків, не спроможних до інновацій, а також формування управлінських рішень щодо підвищення інноваційності банківської діяльності.

\section{Література}

1. Бирюков А. И. Формирование инновационных кластеров в высокотехнологичных отраслях промышленности (на при- мере ОПК России) : автореф. дис. ... на получение степени докт. эконом. наук : спец. 08.00.05 «Экономика и управление народным хозяйством» / А.И. Бирюков. - М., 2007. -40 с.

2. Єжакова Н. В. Оцінка взаємодії елементів інноваційного кластера / Н. В. Сжакова // Экономика Крыма. - 2010. - № 4. - С. 20-25.

3. Кузьмина Ю. Д. Инновационные кластеры: сущность и особенности / Ю. Д. Кузьмина // Современные тенденции в экономике и управлении: новый взгляд. - 2011. - № 11-1. C. 21-26.

4. Саяпина К. В. Формирование инновационных кластеров как инструмент эффективного экономического управления / К. В. Саяпина // Эффективное антикризисное управление. - 2013. - № 6. - С. 88-95.

5. Горбань С. Ф. Особливості функціонування інноваційних кластерів в Україні / С. Ф. Горбань, О. В. Чумак // Наука й економіка. - 2014. - № 3(35). - С. 224-230.

6. Іванов Ю. Б. Теоретичні підходи до розробки класифікації кластерних структур / Ю. Б. Іванов, О. В. Анненкова [Електронний ресурс]. - Режим доступу: http://vlp.com.ua/files/14_35.pdf.

7. Смолич Д. В. Концептуальні засади формування інноваційних кластерів в умовах транскордонного співробітництва регіонів / Д. В. Смолич [Електронний ресурс]. - Режим доступу:

http://ena.lp.edu.ua:8080/bitstream/ntb/15940/1/31 _206211_Vis_725_Ekonomika.pdf.

8. Офіційний веб-сайт Національного банку України [Електронний ресурс]. - Режим доступу: https://bank.gov.ua
9. Сгоричева С. Б. Банківські інновації: навч. посіб. / С.Б. Сгоричева. - К.: Центр учбової літератури, 2010. - $208 \mathrm{c}$.

10. Кривич Я. М. Вплив інновацій на стратегічний розвиток банку / Я. М. Кривич [Електронний pecypc]. - Режим доступу: http://dspace.uabs.edu.ua/- bitstream/123456789/797/3/4.pdf.

11. Банки и банковское дело / Под ред. д.э.н., проф. И.Т. Балабанова. - СПб.: Питер, 2013. - $256 \mathrm{c}$.

12. Матвійчук Н. М. Розвиток інновацій у сучасній банківській сфері України / Н. М. Матвійчук, Н. Ю. Бурлачук, Ж. В. Гарбар // Молодий вчений. - 2015. - № 5 (20). - Ч. 2.

13. Меда Н. С. Поняття банківського товару і його зв'язок із категоріями «банківський продукт», «банківська послуга» та «банківська операція» / Н. С. Меда // Збірник наукових праць. - 2014. - Вип. 38. - С. 196-204.

14. Погореленко Н. П. Фінансові інновації у розвиток банківського сектору / Н. П. Погореленко // Коммунальное хозяйство городов . - 2004. - № 54. - С. 200-205.

15. Золотарьова O. B. Інноваційні банківські продукти та специфіка їх упровадження в Україні / О. В. Золотарьова, А. А. Чекал // Науковий вісник Херсонського державного університету. - 2016. - №1. - С. 112114 .

16. Левковська Л. В. Формування інноваційних кластерів в Україні / Л. В. Левковська [Електронний ресурс]. - Режим доступу : http://dspace.nbuv.gov.ua/bitstream/handle/123456 789/5902/12-Levkovsjka.pdf

17. Соцька Ю. І. Методологічні засади кластерного аналізу конкурентоспроможності банків України / Ю. І. Соцька // Фінансовокредитна діяльність: проблеми теорії та практики. - 2015. - Вип. 2. - С. 177-185

18. Кльоба Л. Г. Оцінювання рівня інноваційності банківських продуктів і послуг / Л. Г.Кльоба // Ефективна економіка. - 2016. - №6 [Електронний ресурс]. - Режим доступу: http://www.economy.nayka.com.ua/?op=1\&024

19. Оксенюк K. I. Формування та розвиток регіональних інноваційних кластерів / К.І. Оксенюк // Бізнес Інформ. - 2012. - № 9. - С. 47-50.

20. Пуліна T. В. Генезис кластерних об'єднань підприємств / Т.В. Пуліна // Проблеми економіки. - 2013. - № 3. - С. 134-142.

21. Шовкалюк В. С. Кластери та інноваційний розвиток України / В. С. Шовкалюк // Створення та функціонування інноваційних кластерів. Інформаційно-аналітичні матеріали Державного агентства 3 питань науки, інно- 
вацій та інформатизації України [Електронний ресурс]. - Режим доступу : http://www.dknii.gov.ua/images/stories/Stvor_ta_f unk_klasteriv.pdf.

22. Лютий I. O. Банківський маркетинг / I. О. Лютий, О. О. Солодка. - К. : Центр учбової літ., 2009. - 776 с.

\section{References}

1. Biryukov A. I. (2007). Formation of innovation clusters in high-tech industries (for example, Russian defense industry): author. diss. ... receiving a doctor degree in Economy Sciences: Special. 08.00.05 "Economy and Management of the National Economy", 40.

2. Yezhakova N. V. (2010). Evaluation of interaction of elements of innovation cluster. Economy of Crimea, 4, 20-25.

3. Kuzmina Yu. D. (2011). Innovative clusters: essence and features . Modern tendencies in economics and management: a new look, 11-1, 2126.

4. Sayapina K. V. (2013). Formation of innovation clusters as an instrument of effective economic management. Effective anti-crisis management, 6, 88-95.

5. Gorban S. F. (2014). Features of functioning of innovative clusters in Ukraine. Science and economics, 3 (35), 224-230.

6. Ivanov $Y$ u. B. (2009). Theoretical approaches to the development of cluster structure classification. Retriveid from: http://vlp.com.ua/files/14_35.pdf.

7. Smolich D. V. Conceptual bases of formation of innovative clusters in conditions of cross-border cooperation of regions. Retriveid from: http://ena.lp.edu.ua:8080/bitstream/nt.pdf.

8. Official Website of the National Bank of Ukraine. Retriveid from: https://bank.gov.ua

9. Yegoricheva S. B. (2010) Banking innovations: textbook. tool. Kyiv: Center for Educational Literature, 208.

10. Kryvich $Y a$. M. Influence of innovations on strategic development of the bank Retriveid from: http://dspace.uabs.edu.ua.pdf.

11. Balabanova, I. T. (2013). Banks and

Стаття надійшла
до редакції : 13.08 .2019 p.

Banking. St. Petersburg: Piter, 256.

12. Matviychuk N. M. \& Burlachuk N. Yu. \& Harbar Zh. V. (2015) Development of innovations in the modern banking sphere of Ukraine. Young scientist, 5 (20), Part 2.

13. Meda N. S. (2014) The concept of banking product and its relation to the categories "banking product", "banking service" and "banking operation". Collection of scientific papers, 38, 196204.

14. Pogorelenko N. P. (2004) Financial innovations in the development of the banking sector. Municipal Economy of Cities, 54, 200-205.

15. Zolotaryova O. V. (2016) Innovative banking products and the specifics of their implementation in Ukraine. Scientific Bulletin of the Kherson State University, 1, 112-114.

16. Levkovska L. V. Formation of innovative clusters in Ukraine Retriveid from: http://dspace.nbuv.gov.ua/bitstream/handle/123456 789/5902/12-Levkovsjka.pdf

17. Sotskaya Yu. I. (2015). Methodological foundations of cluster analysis of competitiveness of Ukrainian banks. Financial and credit activity: problems of theory and practice, 2, 177-185.

18. Kleoba L. G. (2016). Assessing the level of innovation of banking products and services. Effective Economics, 6 Retriveid from: http://www.economy.nayka.com.ua/?op=1\&z=502 4

19. Okseniuk K. I. (2012). Formation and development of regional innovation clusters. Business Inform, 9, 47-50.

20. Pulina T. V. (2013). Genesis of cluster associations of enterprises. Problems of Economics, 3, 134-142.

21. Shovkaliuk V. S. Clusters and innovative development of Ukraine. Creation and functioning of innovation clusters. Information and analytical materials of the State Agency for Science, Innovation and Informatization of Ukraine. Retriveid from: http://www.dknii.gov.ua/image.

22. Lyitiy I. O. \& Solodka O. O. (2009). Banking marketing. K.: Center for Academic Lit., 776.

\section{Стаття прийнята \\ до друку: 27.09.2019 p.}

\section{Бібліографічний опис для цитування :}

Татар М. С. Створення банківських кластерів для підвищення інноваційності банківської системи України / М. С. Татар, Ю. А. Нужнова, О. О. Косяк // Часопис економічних реформ. - 2019. № 3 (35). - C. 56-65. 